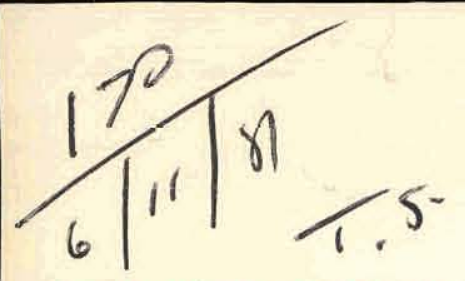

\section{ENEERGY}

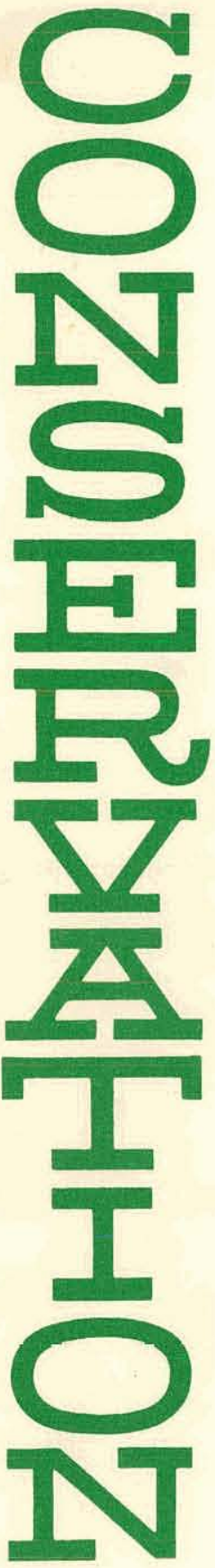

(F) Bins-112

On.2729

NIS.25

DOE/ET/15208-T1(Vol.2)

\title{
DESIGN AND DEVELOPMENT OF STIRLING ENGINES FOR STATIONARY POWER GENERATION APPLICATIONS IN THE 500 TO 3000 HORSEPOWER RANGE
}

Phase I. Final Report (Volume 2)

\section{October 1980}

Work Performed Under Contract Nos. AC02-79ET15208

W-31-109-ENG-38

Foster-Miller Associates, Inc.

Waltham, Massachusetts

\section{U. S. DEPARTMENT OF ENERGY}




\section{DISCLAIMER}

This report was prepared as an account of work sponsored by an agency of the United States Government. Neither the United States Government nor any agency Thereof, nor any of their employees, makes any warranty, express or implied, or assumes any legal liability or responsibility for the accuracy, completeness, or usefulness of any information, apparatus, product, or process disclosed, or represents that its use would not infringe privately owned rights. Reference herein to any specific commercial product, process, or service by trade name, trademark, manufacturer, or otherwise does not necessarily constitute or imply its endorsement, recommendation, or favoring by the United States Government or any agency thereof. The views and opinions of authors expressed herein do not necessarily state or reflect those of the United States Government or any agency thereof. 


\section{DISCLAIMER}

Portions of this document may be illegible in electronic image products. Images are produced from the best available original document. 


\section{DISCLAIMER}

"This book was prepared as an account of work sponsored by an agency of the United States Government. Neither the United States Government nor any agency thereof, nor any of their employees, makes any warranty, express or implied, or assumes any legal liability or responsibility for the accuracy, completeness, or usefulness of any information, apparatus, product, or process disclosed, or represents that its use would not infringe privately owned rights. Reference herein to any specific commercial product, process, or service by trade name, trademark, manufacturer, or otherwise, does not necessarily constitute or imply its endorsement, recommendation, or favoring by the United States Government or any agency thereof. The views and opinions of authors expressed herein do not necessarily state or reflect those of the United States Government or any agency thereof."

This report has been reproduced directly from the best available copy.

Available from the National Technical Information Service, U. S. Department of Commerce, Springfield, Virginia 22161.

Price: Printed Copy A03

Microfiche A01 
DOE/ET/15208-T1 Vol.2)

Distribution Catege y UC-93

\author{
PHASE I FINAL REPORT-VOLUME II \\ DESIGN AND DEVELOPMENT OF \\ STIRLING ENGINES FOR STATIONARY \\ POWER GENERATION APPLICATIONS \\ IN THE 500 TO 3000 \\ HORSEPOWER RANGE
}

October 1980

Prepared for:

Argonne National Laboratory

Components Technology Division

Prepared by:

Foster-Miller Associates, Inc. 350 Second Avenue

Waltham, Massachusetts 02154

Sponsored by:

Department of Energy

Assistant secretary fur Fossil Fuel

office of Coal Utilization 
6

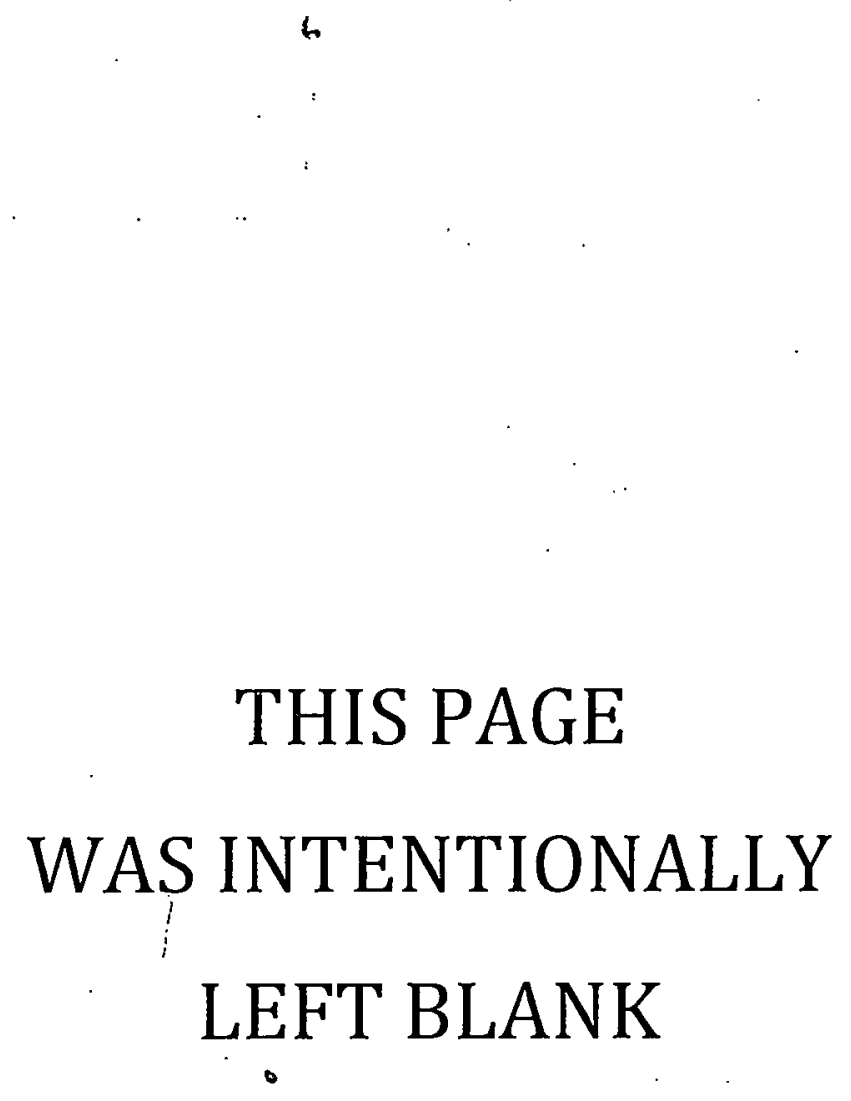




\section{EXECUTIVE SUMMARY}

A program plan for the implementation of the proposed conceptual designs through the remaining four phases of the overall large stirling engine development program has been prepared. Phase II, Preliminary Engine Designs, is divided into eight tasks. The objective of Phase II is to prepare more detailed designs of the conceptual designs prepared in Phase $I$. At the conclusion of Phase II, a state-of-the-art design will be selected from the candidate designs developed in Phase I for development.

Phase III, Final Engine Design, is divided into eight tasks. The objective of Phase III is to prepare manufacturing drawings of the candidate engine design. Also, detailed manufacturing drawings of both $373 \mathrm{~kW}(500 \mathrm{hp})$ and $746 \mathrm{~kW}$ (1000 hp) power pack skid systems will be completed. The power pack skid systems will include the generator, supporting skid, controls, and other supporting auxiliary subsystems. The stirling cycle engine system (combustion system, stirling engine, and heat transport system) will be mounted in the power pack skid system.

Phase IV, Fabrication, is divided into seven tasks. The objective of Phase IV is to procure parts for prototype engines and two power pack skid systems. Engines No. 1 and 2 will be assembled.

Phase V, Testing and Demonstration, is divided into 12 tasks. The objective of Phase $\mathrm{V}$ is to perform extensive laboratory and demonstration testing of the stirling engines and power pack skid systems, to determine the system performance and cost and commercialization strategy. Two stirling cycle engine systems and the $373 \mathrm{~kW}(500 \mathrm{hp})$ power pack skid system will be tested at FMA and three stirling cycle engine systems and the $7416 \mathrm{~kW}$ 
(1000 hp) power pack skid system will be tested at TCM. Near the conclusion of the development and demonstration testing, a commercialization plan will be prepared.

A detailed program schedule for Phases II through $V$ has been prepared. Phases II and III are scheduled for 12 months each. Phase IV is scheduled for 18 months, and Phase V is scheduled for 30 months.

Both FMA and TCM jointly prepared the cost estimates for the completion of Phases II through $V$. The costs are summarized in Table ES-1. The costs are budgetary and were prepared on a cost-plus-fixed-fee basis, and do not include inflation adjustments. Thus the values are for 1980 dollars.

Table ES-1. Summary of Estimated Costs for Phases II Through V

\begin{tabular}{|c|c|}
\hline Phase & Estimated cost \\
\hline Phase II & $\$ 2,374,000$ \\
Phase III & $3,437,000$ \\
Phase IV & $9,143,000$ \\
Phase V & $7,109,000$ \\
& $\$ 22,063,000$ \\
\hline
\end{tabular}




\section{EXECUTIVE SUMMARY}

1.

INTRODUCT ION

2 .

DESCRIPTION OF PHASE II TASKS

2.1

Task 1 - Review Conceptual Designs

2.2 .

Task 2 - System Analysis

2.3 .

Task 3 - Component Design

Task 4 - System Thermodynamic

2.5 Task 5 - Manufacturing Assessment and Cost Analysis

Task 7 - Critical Component Development and Testing

Task 2 - Power Pack Skid System Design (500 and $1000 \mathrm{hp}$ )

3.3 Task 3 - System Thermodynamic

3.4 Task 4 - Final Design Specifications 25

3.5 Task 5 - Preparation of Manufacturing Drawings/Parts List

3.6 Task 6 - Manufacturing Assessment and Cost Analysis

3.7 Task 7 - Critical Component Development and Testing. 
4.4 Task 4 - System Preliminary Checkout (Engines No. 1 and No. 2)

4.5 Task 5 - Procure Power Pack Skid Systems (500 and $1000 \mathrm{hp}$ )

4.6 Task 6 - Procure Components for

Engines No. 3 and No. 4

4.7 Task 7 - Critical Components

Development and Testing

Task 8 - Reports

5 .

DESCRIPTION OF PHASE V TASKS

Task 1 - Startup Tests and Checkout

(Engines No. 1 and No. 2).

5.2 Task 2 - Performance, Controls, and Emissions Development Testing

5.3

Task 3 - System Assembly (Engines No. 3 and No. 4)

5.4

Task 4 - Durability Testing

5.5

Task 5 - Procure Components for Engines No. 5 and No. 3 (Rebuild)

5.6

Task 6 - Rebuild Engine No. 3

5.7

Task 7 - System Assemble (Engine No. 5)

5.8

Task 8 - Assemble Power Pack Skid Systems

5.9

Task 9 - Preliminary Testing of $1000 \mathrm{hp}$

5.10 Power Pack Skid System

Task 10 - Demonstration Testing of $1000 \mathrm{hp}$ Power Pack Skid System

Task 11 - Commercialization Plan 
Figure No.

1.

2.

3.

4.

3

$\cdot$

Proposed Phase II Program Schedule

Proposed Phase III Program Schedule.

Proposed Phase IV Program Schedule

Proposed Phase V Program Schedule

\section{LIST OF TABLES}

Table No.

$$
\text { ES }-1 \text {. }
$$

1.

Summary of Estimated Costs for
Page No.

9

10

11

12
Page No.

Summary of Estimated Costs for Phases II through $\mathrm{V}$

iv Phases II through V 


\section{INTRODUCTION}

This volume contains the program plan for the implementation of the proposed conceptual designs through the remaining four phases of the overall large stirling engine development program. Each task in the technical program is described in the order of performance. The tasks are grouped into four phases. Phase II, Preliminary Engine Designs, is divided into eight tasks:

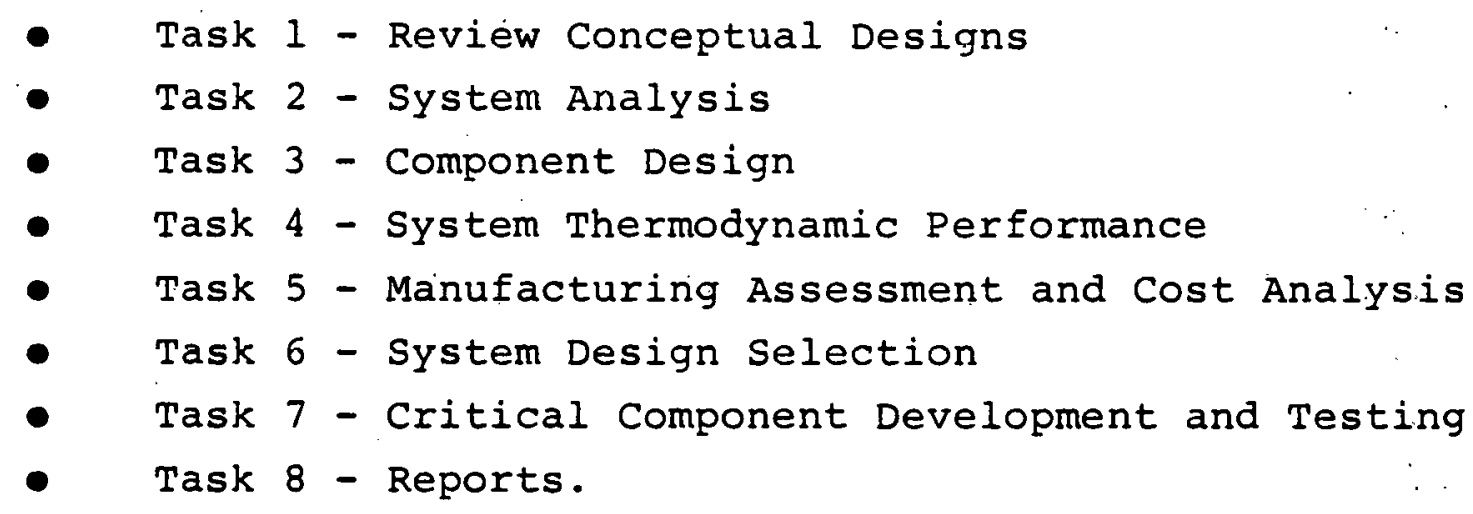

The objective of Phase II is to prepare more detailed designs of the conceptual designs prepared in Phase I. At the conclusion of Phase II, a state-of-the-art design will be selected from the candidate designs developed in Phase I for development.

Phase III, Final Engine Design, is divided into eight tasks:

\footnotetext{
- Task 1 - System Detailed Design

- Task 2 - Power Pack Skid System Design (500 and 100 hp)

- Task 3 - System Thermodynamic Performance Analysis

- Task 4 - Final Design Specifications

- Task 5 - Preparation of Manufacturing Drawings/Part List

- Task 6 - Manufacturing Assessment and Cost Analysis

- Task 7 - Critical Component Development and Testing

- Task 8 - Reports.
} 
The objective of Phase III is to prepare manufacturing drawings of the candidate engine design. Also detailed manufacturing drawing of both $500 \mathrm{hp}$ and $1000 \mathrm{hp}$ power pack skid systems will be completed. The power pack skid systems will include the generator, supporting skid, controls, and other supporting auxiliary subsystems. The Stirling cycle engine system (combustion system, stirling engine, and heat transport system) will be mounted in the power pack skid system.

Phase IV, Fabrication, is divided into seven tasks:

- Task 1 - Fabricate Components for Engines No. 1 and 2

- Task 2 - Test Cell Facility Preparation

Task 3 - System Assembly (Engines No. 1 and 2)

Task 4 - System Preliminary Checkout (Engines No. 1 and 2)

- Task 5 - Procure Power Pack Skid: Systems (500 and $1000 \mathrm{hp}$ )

- Task 6 - Procure Components for Engines No. 3 and 4

- Task 7 - Critical Component Development and Testing.

The objective of Phase IV is to procure parts for prototype engines and two power pack skid systems. Engines No. 1 and 2 will be assembled.

Phase $v$, Testing and Demonstration, is divided into twelve tasks : 
Task 1 - Startup Tests and Checkout (Engines No. 1 and 2)

- Task 2 - Performance, Controls, and Emissions Development

- Task 3 - System Testing Assembly (Engines No. 3 and 4)

- Task 4 - Durability Testing

- Task 5 - Procure Components for Engines No. 5 and 3 (rebuild)

- Task 6 - Rebuild Engine No. 3

- $\quad$ Task 7 - System Assembly (Engine No. 5)

- $\therefore$ Task 8 - Assemble Power Pack Skid Systems .

- Task 9 - Preliminary Testing of 1000 hp Power Pack skid system

Task 10 - Demonstration Testing of $1000 \mathrm{hp}$ Power Pack skid system

- Task 11 -. Commercialization Plan

- Task 12 - Reports.

The objective of Phase $\mathrm{V}$ is to perform extensive laboratory and demonstration testing of the stirling engines and power pack skid systems to determine the system performance and cost and commercialization strategy. Two stirling cycle engine systems and the $500 \mathrm{hp}$ power pack skid system will be tested at 
FMA; three additional stirling cycle engine systems and the $1000 \mathrm{hp}$ power pack skid system will be tested at Teledyne Continental Motors (TCM). Near the conclusion of the development and demonstration testing a commercialization plan will be prepared.

The overall program objective is the development and eventual commercialization of a large stirling: cycle engine which is powered by unconventional fuels such as coal, solar, low Btu gas, etc. In addition, the engines should exhibit high efficiency, reliability, serviceability, fuel flexibility, and low initial capital costs. The cost goal for the future production line Stirling engines utilizing nonscarce fuels is that they be competitive with conventional prime movers on a life-cycle cost basis.

Foster-Miller Associates, Inc. (FMA) has assembled a team of engine companies and consultants to accomplish successfully the proposed large Stirling engine development program. FMA will be responsible for program management, mechanical design, thermodynamic analysis, engine development testing, and the coordination of the subcontractors' efforts. TCM, a diesel engine manufacturer, is responsible for the mechanical design, engine fabrication, engine development testing, manufacturing assessment, product cost assessment, and commercialization plan preparation. The Stirling engine consultants, who are Mr. Stig Carlquist, former managing director of United stirling of Sweden, and Professor Joseph L. Smith, Jr. of the Massachusetts Institute of Technology (MIT) are responsible for providing previous Stirling engine technology, design evaluation, development testing analysis, and other technical guidance. The remaining company participating in the program is SUNPOWER, Inc. 
which is presided over by Mr. William Beale, developer of the free piston Stirling engine. SUNPOWER is responsible for providing previous stirling engine technology, thermodynamic analysis, design evaluation, and development testing analysis. Finally, FMA will employ the consulting services of Thermacore, Inc. which will be responsible for evaluating heat pipe concepts for Stirling engines.

The FMA/TCM/SUNPOWER/Stirling engine consultants project team is ideally suited to meet the objectives of the program; that is, the design, development, demonstration, and eventual commercialization of a fuel-flexible stirling cycle stationary engine. FMA brings to the program substantial expertise in combustion technology, heat transport systems, and heat engine development. TCM is a large engine manufacturer and has extensive experience'in manufacturing small lots of custom designed engines; in fact, TCM is the largest speciality engine manufacturer in the United States. SUNPOWER, Inc. is the oldest Stirling engine manufacturer in the United States.

A detailed program schedule for Phases II through $V$ is presented in Figures 1 through 4. Phases II and III are scheduled for 12 months each, Phase IV is scheduled for 18 months, and Phase $\mathrm{V}$ is scheduled for 30 months. Detailed descriptions of the work plans for each task are presented in later sections. A summary of the program cost is as follows:

\begin{tabular}{|c|c|c|}
\hline Phase & $\begin{array}{l}\text { Duration } \\
\text { (months) }\end{array}$ & Cost $(\$)$ \\
\hline II & 12 & $2,374,000$ \\
\hline III & 12 & $3,437,000$ \\
\hline IV & 18 & $9,143,000$ \\
\hline v & 30 & $7,109,000$ \\
\hline Total & 72 & $22,063,000$ \\
\hline
\end{tabular}




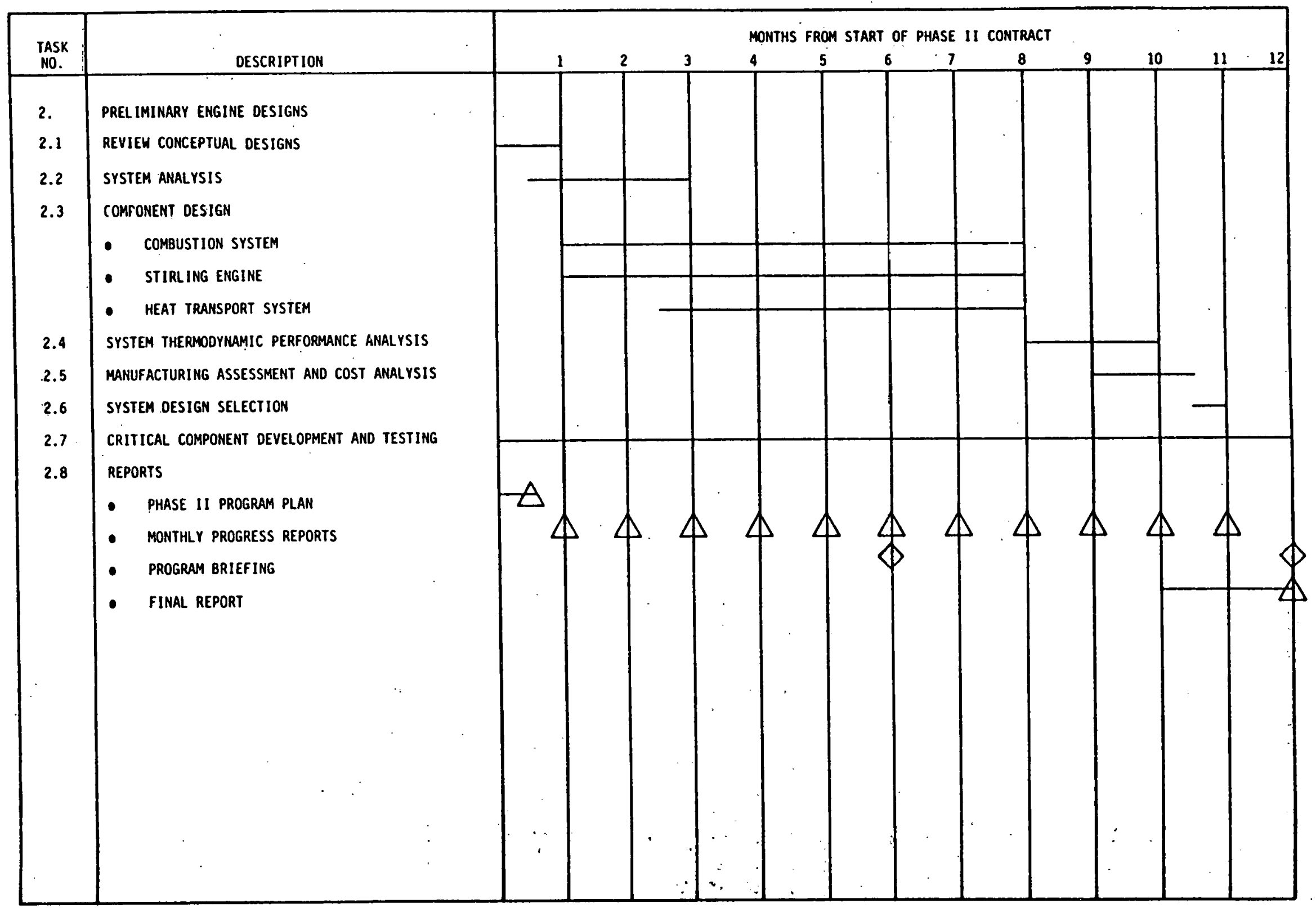

Figure 1. Proposed Phase II Program Schedule 


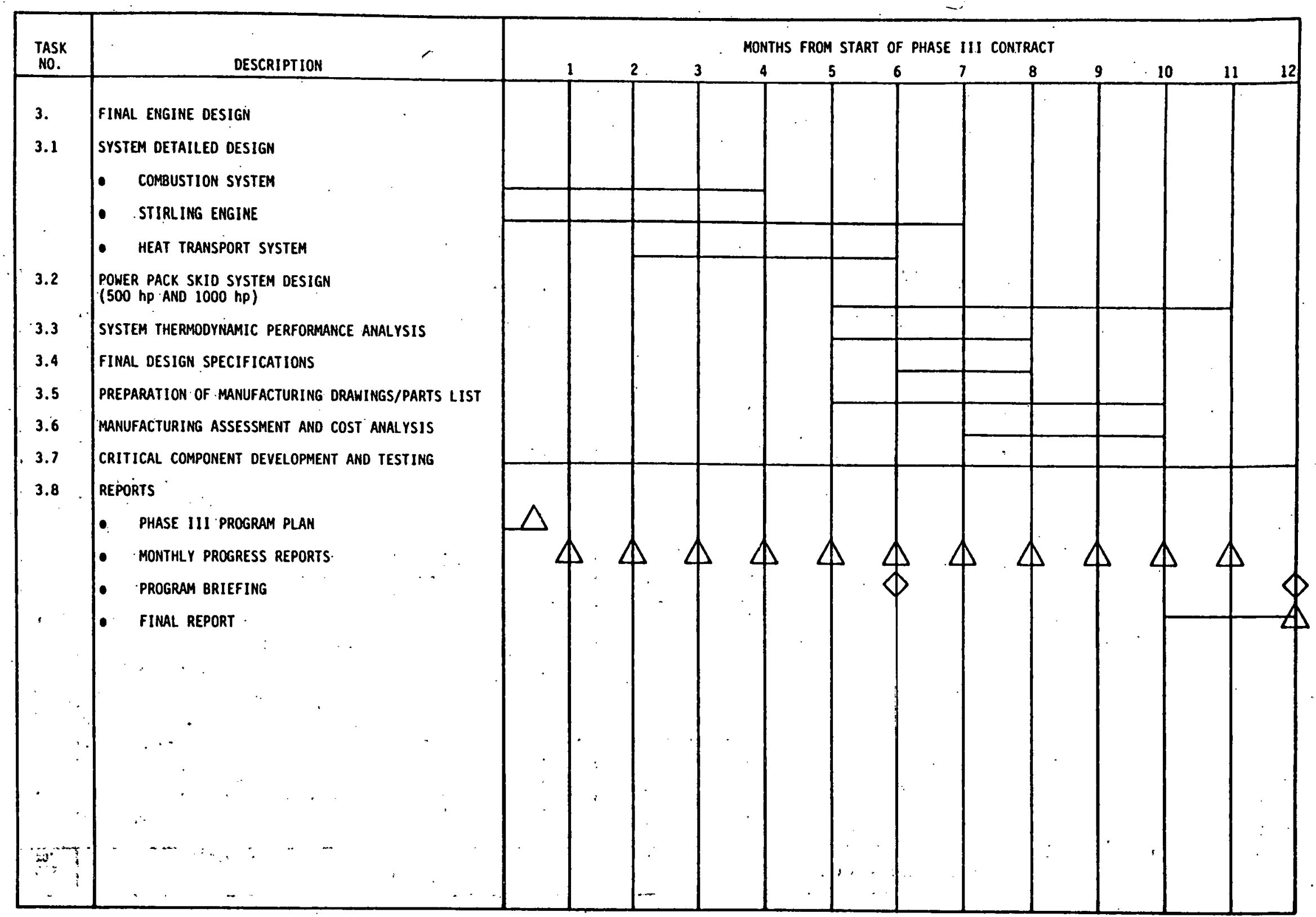

Figure 2: Proposed Phase III Program Schedule 


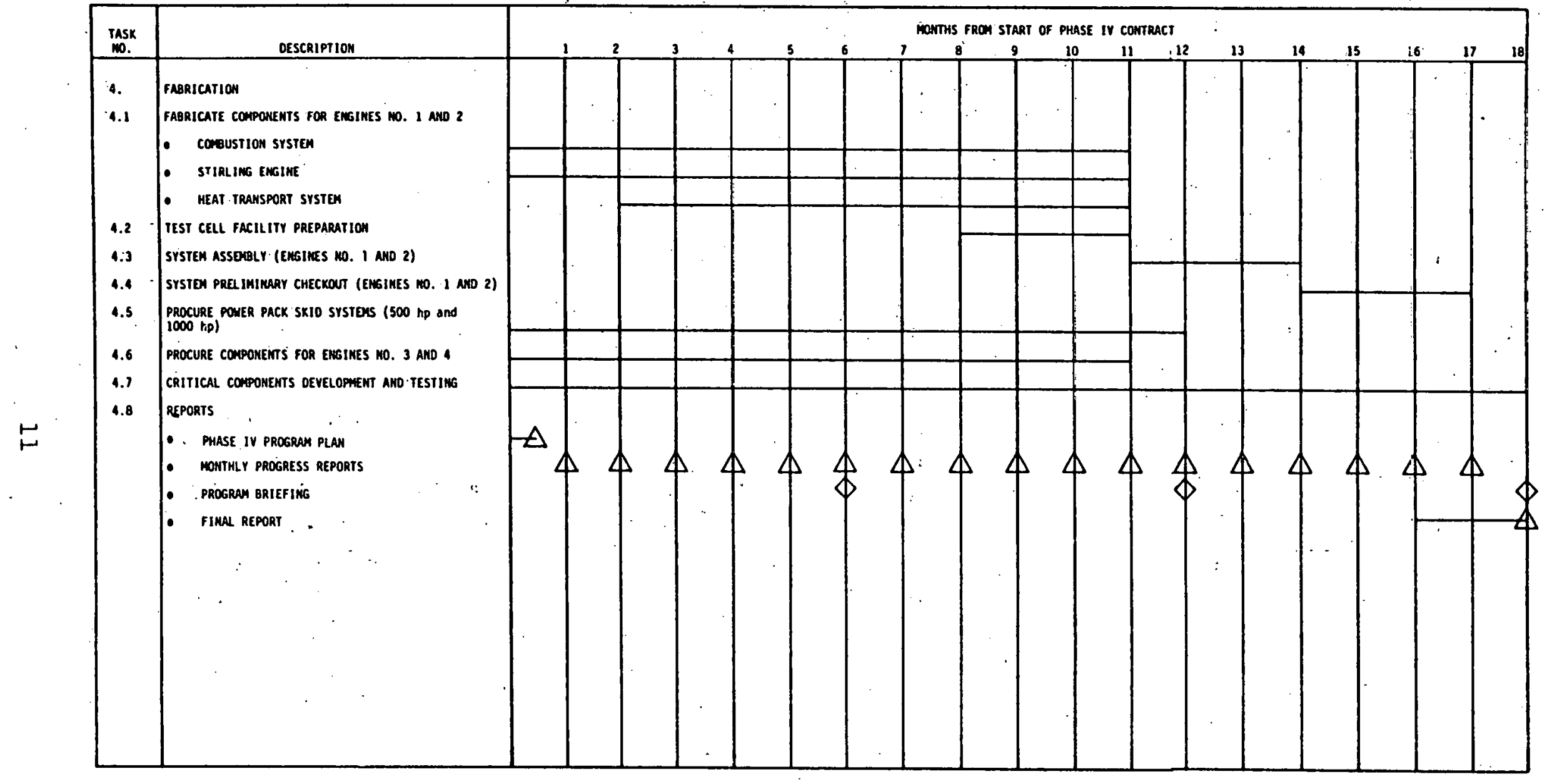

Figure 3. Proposed Phase IV Program Schedule 


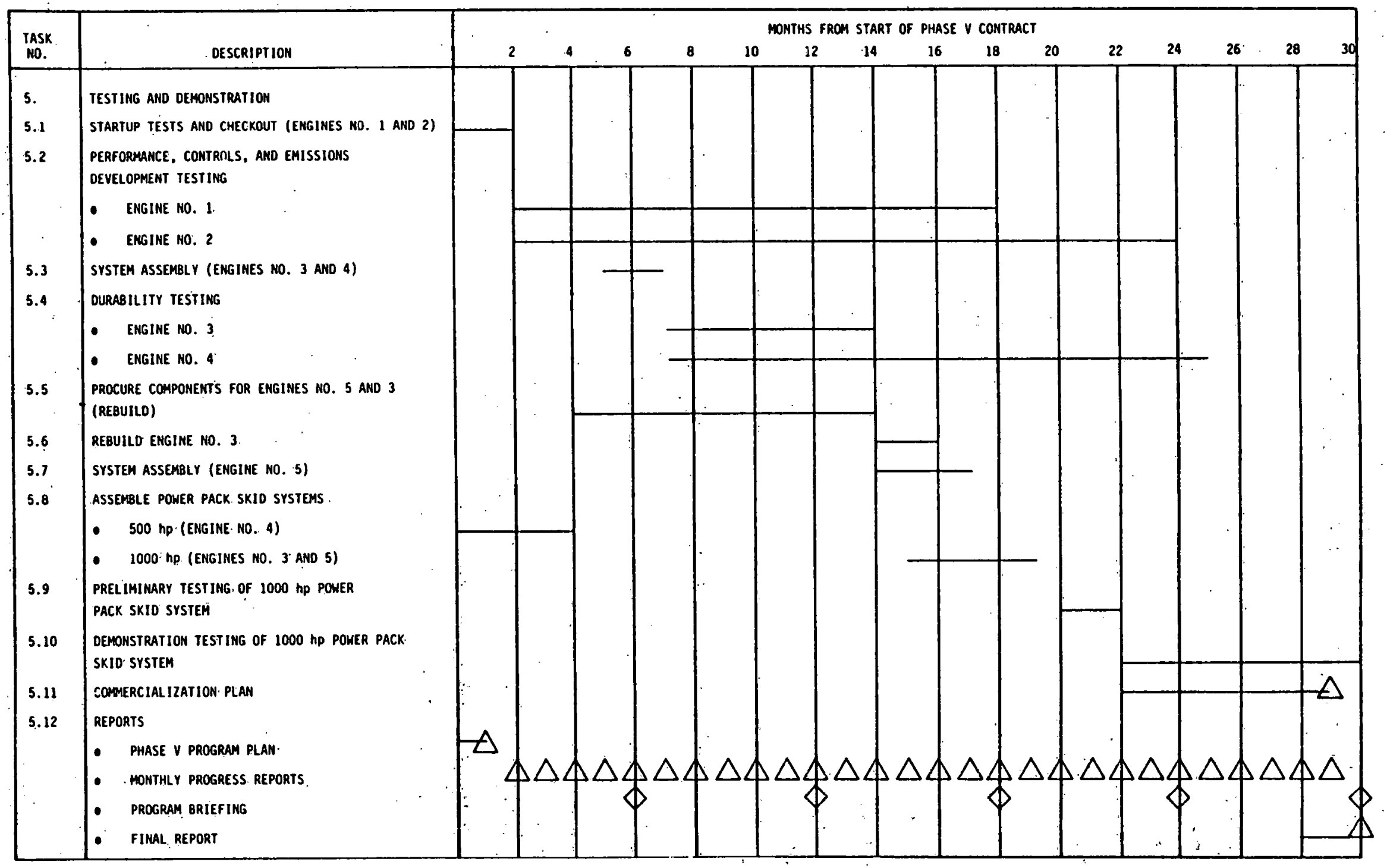

Figure 4. Proposed Phase V Program Schedule 


\section{DESCRIPTION OF PHASE II TASKS}

\subsection{Task 1 - Review Conceptual Designs}

The purpose of Task $I$ is to review all the system designs prepared in Phase $I$, which culminated in the preparation of more than one state-of-the-art conceptual design of large Stirling cycle engine systems for stationary power generation. The projected thermodynamic performances, designs specifications, conceptual drawings, materials specifications, and estimated manufacturing costs will be reviewed for each design prior to performing the preliminary system analysis and preliminary component design efforts.

\subsection{Task 2 - System Analysis}

A thermodynamic system analysis will be performed for each of the candidate stirling engine configurations. The first procedure will be to determine the relevant design specifications such as:

\footnotetext{
- Piston diameter

- Piston stroke

- Displacement volume

- Clearance space

- Engine speed

i Desired engine output power

- Material specifications and dimensions

- Regenerator dimensions

- Heater head configuration

- Heater head and cooling water temperatures

- Working fluid, etc.,

from the candidate Stirling engine designs.
} 
This design information shall be used as input to the FMA second order computer program and the Sunpower third order computer program. A series of coupled thermodynamic - fluid mechanical - heat transfer - dynamic calculations shall be performed by the computer programs to obtain the following output:

- Thermodynamic state points (pressure, temperature, and mass) in the compression space, expansion space, and regenerator of the Stirling cycle engines

- $\quad$ P $-V$ diagram

- Power loss contributions

- Heat input loss contributions

- Thermal stresses in the heater tube and cylinder walls

- Thermal efficiency of the engine designs.

This output information shall be fed back to the mechanical design drawings so that engineering design changes can be performed to improve engine performance and to reduce manufacturing costs.

In a similar fashion a thermodynamic system analysis will be performed for the candidate conventional combustion system designs and heat transport system designs.

The thermodynamic system analysis will be done concurrently with the component design and there shall be constant design iterations due to the results of the thermodynamic system analysis. 


\subsection{Task 3 - Component Design}

This task includes the design and evaluation of the three major components of the large stationary stirling engine:
- Combustion system
- Stirling engine
- Heat transport system.

Each will be discussed below.

\section{Combustion System}

The candidate combustion systems which burn oil or gas will be examined and the proposed conceptual designs will be further refined. The present design concepts for the conventional oil and gas combustion systems (which include combustor, air preheater, and blower) are similar to the combustion systems developed by FMA for residential and commercial applications. These systems include energy efficiency concepts that FMA developed for DOE funded oil and gas combustion systems programs.

In addition, the candidate near-term coal combustion systems will be examined and the proposed conceptual designs will : be further refined. Presently, FMA believes that the atmospheric fluidized bed combustion system, either conventional or Wormser Grate is the coal combustion system that is suitable for nearterm development. The proposed designs will be prepared or modified so that they will integrate with the stirling engine design and will easily replace the proposed oil and gas combustion systems. 


\section{Stirling Engine}

The proposed candidate mechanical configuration designs will be reviewed and will be further investigated and refined. The preliminary mechanical designs will include heat exchanger configuration, engine configuration (single acting or double acting), cylinder/piston arrangement, drive configuration, and power control method. The proposed engine configuration that shall be investigated is the double-acting $V$ arrangement, and critical design areas such as lubrication, seals, control system, heater head, and regenerator will be further examined and preliminary mechanical drawings will be prepared.

The mechanical design configuration will be prepared so that the combustion systems utilizing conventional fuels such as oil and gas and nonconventional fuels such as coal, liquid coal, low Btu gas, and solar can be easily integrated into the final engine design.

\section{Heat Transport System}

The proposed candidate heat transport system will be reviewed and will be further investigated and designed. The preliminary heat transport system designs include direct heat transfer systems employing exhaust gas recirculation (EGR) and indirect heat transport systems such as heat pipes and gas circulation loops which are required for the utilization of an atmospheric fluidized bed combustion system with a stirling engine.

The preliminary mechanical design of the heat transport systems will be prepared to accommodate fuel flexibility. for the Stirling engine. 
The Stirling cycle engine system designs shall be prepared in order to satisfy the design specifications and requirements which are the following:

Power range of 500 to $3000 \mathrm{hp}$

Engine design speed compatible with a $60 \mathrm{~Hz}$ electric generator

- Design exit temperature of the cooling water is $80^{\circ} \mathrm{C}$ with an overall operating range between $20^{\circ}$ and $120^{\circ} \mathrm{C}$

- Design shaft power output efficiency of 40 percent based on a cooling water temperature of $80^{\circ} \mathrm{C}$. (This shaft power output efficiency does not include the combustion system and air preheater inefficiencies)

- Stirling engine and combustion system production costs within 150 percent of a comparable diesel engine for the case of liquid fuel combustors and 180 percent for the case of solid fuel combustors

- Minimum mean time between overhauls (MTBO) of 10,000 hr. Critical components which do not meet this MTBO requirement will be designed for rapid replacement

- Preliminary designs should be applicable to stirling engines of any size within the range of 500 to $3000 \mathrm{hp}$

The preliminary system designs are to be suitable/ feasible for eventual fabrication and testing of a prototype Stirling cycle stationary engine in the 500 to 3000 hp range. 
Both the mechanical design and thermodynamic system analysis are done concurrently, and thus there will occur constant design iterations due to the results of the thermodynamic system analysis. and the results of the critical component development and testing described in Task 7.

\subsection{Task 4 - System Thermodynamic Performance Analysis}

At the conclusion of Task 3 - Component Design, a system thermodynamic performance analysis will be performed for alz of the candidate systems designs. For each of the candidate preliminary designs, a table of projected thermodynamic performance parameters will be prepared. These include the following:

- Shaft power output efficiency

- Part load performance

- Operating pressures

- Working fluids

- Efficiency and performance curves as a function of cooler and heater temperatures

- Regenerator effectiveness, etc.

This information will be used in conjunction with other design data, production cost estimates, manufacturing assessment, reliability, and maintainability estimates to determine the ranking of the candidate preliminary designs of the stirling cycle engine for stationary power generation. 


\subsection{Task 5 - Manufacturing Assessment and Cost Analysis}

For each of the candidate preliminary designs of the stirling cycle engine systems prepared by FMA, TCM, and SUNPOWER, Inc., a cost analysis and a manufacturing assessment shall be performed. The cost analysis shall include:

- Manufacturing costs of the engine for production quantities of 1,000 and 10,000. units/year. The engine manufacturing cost, which is the summation of the variable and fixed costs, will include the direct labor costs, material costs, and overhead costs

- Engine operating costs

- Maintenance costs

- Life cycle costs

- Criteria for estimating the prementioned cost factors.

The manufacturing assessment shall include factors such as manufacturing technology, production feasibility, and power level growth potential. The manufacturing technology shall be identified in terms of current state-of-the-art manufacturing technology, manufacturing development technology, or projected manufacturing technology. A detailed table showing the major components and required manufacturing technology shall be prepared with a discussion of the critical manufacturing technology assessment.

\subsection{Task 6 - System Design Selection}

At the conclusion of Task 5 - Manufacturing Assessment and Cost Analysis, a system design will be selected from the portfolio of candidate preliminary system designs investigated 
during Phase II. A design evaluation matrix shall be developed to evaluate the candidate preliminary system designs. Technical factors such as thermodynamic performance and reliability, economic factors such as initial cost and operating cost; and production and manufacturing feasibility factors shall be included in the design evaluation matrix. A technical/management evaluation team shall be established by FMA, TCM; and

SUNPOWER, Inc. to select the candidate preliminary engine designs and to rank them both technically and economicaliy.. From these results the candidate preliminary system designs shall be: ranked in order of commercialization potential.

\subsection{Task 7 - Critical Component Development and Testing}

The purpose of this task is to perform critical component experiments and evaluate technical feasibility and performance characteristics of components and parts of the system for which the design and performance cannot be established within a reasonable confidence level. It is planned to perform this throughout Phases II, III and IV to reduce overall program risk. Critical component development and testing will include:

- Critical components identification

- Critical component testing prototype design

- Fabrication of critical components and associated testing support equipment

- Critical component testing/analysis/design modification recommendations.

Each of these steps will be described in the following paragraphs. 


\section{Critical Components Identification}

$\therefore$ A design review of the Stirling cycle engine system will be performed. A critical component identification rating method will be developed and ali stirling cycle engine system components and subsystems will be ranked in terms of design complexity, expected thermodynamic performance, reliability and maintainability projections, potential manufacturing development, etc. From the rating analysis several critical components will be selected for component development. Valid engineering arguments justifying the selection of the candidate critical components will be presented.

Examples of possible critical components to be tested are:

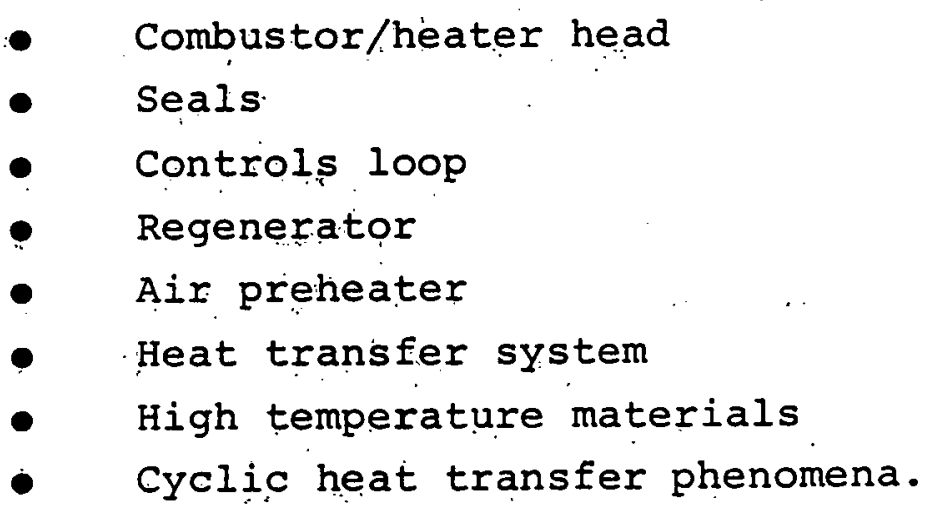

Çrịtical Component Testing Prototype Design

For each of the critical components selected, a component testing prototype with associated testing support equipment will be designed. The testing prototype designs will permit the component to be tested over a wide range of operating conditions. For each of the critical components, a testing protocol which includes:

Identification of the thermodynamic properties required to define the critical component performances 
- Operating conditions over which the critical component is to be tested

- Instrumentation required for property measurement

- Sequence and type of tests to be performed

- Data reduction protocol.

will be prepared. Depending on the critical component, limited endurance testing as well as development testing may be performed during Phases III and IV.

Fabrication of Critical Components and
Associated Testing Support Equipment

From the detailed drawings, the critical components and associated testing support equipment will be fabricated and assembled in both the FMA and TCM test laboratories.

\section{Critical Component Testing/Analysis/Design Modification Recommendations}

Once the fabrication and assembly of the critical components have been completed the critical component testing will be performed in the FMA and TCM test laboratories. The computer programs developed during Phase I will be used to analyze the test results and to help provide corrective actions in the event operating difficulties occur with certain critical components.

Depending on the outcome of the results of the critical component testing program, recommendations for design modifications will be made and incorporated into the final detailed designs which are prepared in phase III. Also, recommendations for life cycle testing of certain components will be made. Component life cycle testing will be performed in phases III and IV. 
It is important that critical component testing be conducted as soon as possible so that design modifications can be made during the evolution of the engine design in Phases II and III.

\subsection{Task 8 - Reports}

A detailed Phase II program plan which includes a technical description of each task, a management plan, and a cost plan will be prepared within the first 2 weeks after the contract for Phase II is awarded.

FMA will be responsible for preparing the monthly progress reports and the final report so that all work performed during Phase II is documented. The monthly progress reports will include a project status report and a cost report (Form 65).

In addition, two oral program briefings will be provided at 6 month intervals. 


\section{DESCRIPTION OF PIIASE III TASKS}

\subsection{Task 1 - System Detailed Design}

The purpose of this task is to prepare a final design of the stirling cycle engine system selected for development in Phase II. The system detailed design is divided into three subsystems:

\footnotetext{
- Combustion system

- Stirling engine

- Heat transport system.
}

The final subsystem designs will be prepared in more detail than the preliminary design as described in Phase II. Also an overall engine system final detailed layout drawing will be prepared.

The final mechanical design configuration will be prepared so that combustion systems using oil, gas and coal fuels can be easily integrated into the final design.

\subsection{Task 2 - Power Pack Skid System Design (500 and $1000 \mathrm{hp})$}

Near the completion of Task 1 - System Detailed Design, detailed designs for both a 500 and $1000 \mathrm{hp}$ power pack skid will be prepared. The power pack skids will include the generator, supporting skid, controls, and other supporting auxiliary subsystems. The stirling cycle engine system (combustion system, Stirling engine, and heat transport system) will be mounted in the power pack skid system. The purpose of the power pack skids is to provide demonstration testing of the 500 and $1000 \mathrm{hp}$ prototype stirling cycle stationary power generation systems during Phase V - Testing and Demon'stration. 


\subsection{Task 3 - System Thermodynamic Performance Analysis}

At the conclusion of Task 1 - System Detailed Design, a system thermodynamic performance analysis will be performed for the final system design. A table of projected thermodynamic performance parameters will be prepared. These include the following:

- Shaft power output efficiency

- Part load performance

- Operating pressures

- Working fluid

- Efficiency and performance curves as a function of cooler and heater temperatures

- Regenerator effectiveness, etc.

This information will be used in conjunction with other design data, production estimates, manufacturing assessment, reliability, and maintainability estimates to determine the suitability of the final system design for development and commercialization.

\subsection{Task 4 - Final Design Specifications}

For the Stirling cycle engine system final design, a table of design and thermodynamic specifications and projected performances will be prepared. The table will include a summary of thermodynamic losses, component efficiencies, operating state points, configuration specifications, cost goals, materials specifications, and system performance estimates. 


\subsection{Task 5 - Preparation of Manufacturing Drawings/Parts List}

A complete set of manufacturing drawings, parts lists, and tentative assembly instructions for the stirling cycle engine system will be prepared by TCM and FMA engineers. The drawings will comply with the existing TCM standards to assure ease of integration into its manufacturing operations.

\subsection{Task 6 - Manufacturing Assessment and Cost Analysis}

For the final engine system design prepared by FMA and TCM, a detailed cost analysis and manufacturing assessment shall be performed. The cost analysis shall include:

- Manufacturing costs of the engine for production quantities of 1,000 and 10,000 units per year. The engine manufacturing cost, which is the summation of the variable and fixed costs, will include the direct labor costs, material costs, and overhead costs.

- Engine operating costs.

- Maintenance costs.

- Life cycle costs.

- Criteria for estimating the prementioned cost factors.

The manufacturing assessment shall include factors such as manufacturing technology, production feasibility, and power level growth potential. The manufacturing technology shall be identified in terms of current state-of-the-art manufacturing technology, manufacturing development technology, or projected 
manufacturing technology. A detailed table showing the major components and required manufacturing technology shall be prepared with a discussion of the critical manufacturing technology assessment.

\subsection{Task 7 - Critical Component Development and Testing}

During Phase III, critical component development and testing, which was described in Phase II, will be continued.

\subsection{Task 8 - Reports}

A detailed Phase III program plan which includes a technical description of each task, a management plan, and a cost plan will be prepared within the first 2 weeks after the contract for Phase III is awarded.

FMA will be responsible for preparing the monthly progress reports and the final report so that all work performed during Phase III is documented. The monthly progress reports will include a project status report and a cost report (Form 65).

In addition, two oral program briefings will be provided at 6 month intervals. 


\section{DESCRIPTION OF PHASE IV TASKS}

\subsection{Task 1 - Fabricate Components for Engines No. 1 and No. 2}

From the detailed manufacturing drawings prepared in Phase III, the components for Engines No. 1 and 2 will be fabricated. Both engines will have a shaft power capacity of $500 \mathrm{hp}$. The components will include the combustion system, stirling engine, and heat transport system. It is not determined whether the components will be fabricated at the TCM manufacturing facility or at a small custom engine manufacturing vendor. This decision will be made on a combined low cost estimate and delivery schedule basis.

\subsection{Task 2 - Test Cell Facility Preparation}

The purpose of this task is the preparation of two test cell facilities at TCM and one test cell facility at. FMA for the laboratory testing of Engines No. 1, 3, and 5 at TCM and Engines No. 2 and 4 at FMA. The required test cell facility modifications, utility connections, and instrumentation purchases and installment will be performed.

\subsection{Task 3 - System Assembly (Engines No. 1 and No. 2)}

After the completion of the fabrication of the Engines No. 1 and 2, the engines will be assembled in the TCM test laboratory and installed in the TCM test cell facilities. Instrumentation required for measurements of the thermodynamic state points and performance will be installed on the two prototype engines. 


\subsection{Task 4 - System Preliminary Checkout \\ (Engines No. 1 and No. 2)}

The purpose of this task is to prepare Engines No. 1 and 2 for performance testing which will be conducted in Phase v. For system preliminary checkout, the two engines will be tested at the design point operating conditions for a limited period of time.

\subsection{Task 5 - Procure Power Pack Skid Systems $(500$ and $1000 \mathrm{hp})$}

The detailed manufacturing drawings of the two power pack skids prepared in Phase III will be sent to various manufacturing vendors for estimates of cost for fabrication. A vendor will be selected and the two power pack skids will be manufactured in preparation for demonstration testing during Phase $V$.

\subsection{Task 6 - Procure Components for Engines No: 3 and No. 4}

Components for Engines No, 3 and 4 will be either fabricated at the TCM engine manufacturing facility or purchased from a small custiom engine manufacturing vendor. The detailed manufacturing drawings prepared in Phase III will be used for fabricating the engine components. Both engines will have a shaft power capacity of $500 \mathrm{hp}$.

\subsection{Task 7. Critical Components Development and Testing}

The critical components development and testing program described in Phase III will be continued in Phase IV. 


\subsection{Task 8 - Reports}

A detailed Phase IV Program Plan which includes a technical description of each task, a management plan, and a cost plan will be prepared within the first 2 weeks after the contract for Phase IV is awarded.

FMA will be responsible for preparing the monthly progress reports and the final report so that all work performed during Phase IV is documented. The monthly progress reports will include a project status report and a cost report (Form 65).

In addition, three oral program briefings will be provided at 6 month intervals. 


\section{DESCRIPTION OF PHASE $V$ TASKS}

\subsection{Task 1 - Startup Tests and Checkout (Engines No. 1 and No. 2)}

The purpose of this task is to prepare Engines No. 1 and 2 built in Phase IV for long term performance testing to be performed in Task 2. Engine No. 1 will be installed in the TCM engine test cell facility and Engine No. 2 will be installed in the FMA engine test facility. Both engines will be equipped with instrumentation and startup tests and preliminary checkout testing will be conducted.

\subsection{Task 2 - Performance, Controls, and} Emissions Development Testing

Upon the completion of Task 1 - Startup Tests and Checkout both Engines No. 1 and 2 will undergo extensive development testing: As stated earlier, Engine No. 1 will be tested in the TCM engine test cell facility and Engine No. 2 will be tested in the FMA engine test cell facility.

A testing protocol which includes the following:

- Identification of the thermodynamic properties required to define the components, subsystems, and overall stirling cycle engine system performance

- Operating conditions over which the engine system is to be tested

- $\therefore$ Instrumentation required for thermodynamic property measurements 
- Sequence and type of tests to be performed

- Data reduction protocol

will be prepared.

Development testing as well as endurance testing of both engines will be performed. The engines will be tested at the design point operating conditions and off-design point operating conditions, for example, various part load capacities.

The FMA second order analysis and the SUNPOWER third order analysis will be used to analyze the test results and to provide diagnosis in the event operating difficulties occur with certain components and subsystems.

The test results will be reduced in graphical and tabular form. Depending on the outcome of the development testing, recommendations for design modifications will be made and incorporated into Engines No. 5 and 3 (Rebuild).

\section{3 Task 3 - System Assembly (Engine No. 3 and No. 4)}

The purpose of this task is to assemble Engines No. 3 and 4 . Both engines have a shaft power capacity of $500 \mathrm{hp}$. The engines will be assembled at TCM and Engine No. 3 will remain at TCM and Engine No. 4 will be shipped to FMA to be installed in the 500 hp power pack skid system.

\subsection{Task 4 - Durability Testing}

The purpose of this task is to perform endurance testing of the Stirling cycle engine. Engine No. 3 will be placed in a TCM engine test cell facility and tested under an accelerated Iife environment. Engine No. 4 will be installed in the $500 \mathrm{hp}$ 
power pack skid system, which will be assembled in Task 8 Assemble Power Pack Skid System - and will also be tested under an accelerated life environment at FMA.

The life cycle testing of the two prototype engines will correspond to the expected environment in a typical stationary power system installation, with accelerated start/stop cycles and capacity modulations. The test results for the durability testing of Engines No. 3 and 4 will be reduced to graphical and tabular form. Again, the FMA second order analysis developed during Phase I and the SUNPOWER third order analysis will be used to analyze the test results and to provide diagnosis in the event operating difficulties occur with certain components and subsystems.

A reliability analysis will be performed for the components and subsystems of the prototype stirling cycle engine systems. Failure mode and effect analyses and fault tree analyses will be employed to assess critical components and trouble shooting techniques. Available historical data/generic data and the life cycle test results will be used to generate component failure rates. Statistical procedures will then be employed to predict system and subsystems reliability.

Depending on the outcome of the durability testing of Engines No. 3 and 4 , recommendations for design modifications will be made and incorporated into Engines No. 5 and 3 (Rebuild).

\subsection{Task 5 - Procure Components for Engines No. 5 and No. 3 (Rebuild)}

The purpose of this task is the procurement of the components for Engines No. 5 and 3 which will be rebuilt after Task 4 Durability Testing. Prior to procurement, the design change recommendations obtained during Task 2 and 4 will be incorporated into the final detailed manufacturing drawings for Engines No. 5 and 3 (Rebuild). 
Components for Engines No. 5 and 3 (Rebuild) will be either fabricated at the TCM engine manufacturing facility or purchased from a small custom engine manufacturing vendor. Both engines will have a shaft power capacity of $500 \mathrm{hp}$.

\subsection{Task 6 - Rebuild Engine No. 3}

The purpose of this task is to rebuild Engine No. 3 which will have completed durability testing in Task 4 . The rebuilding of Engine No. 3 will be performed at TCM.

\subsection{Task 7 - System Assemble (Engine No. 5)}

The purpose of this task is to assemble Engine No. 5 which will have a shaft power capacity of $500 \mathrm{hp}$. The engine will be assembled at TCM and will be later installed in the $1000 \mathrm{hp}$ power pack skid system described in Task 8 .

\subsection{Task 8 - Assemble Power Pack Skid Systems}

Both the $500 \mathrm{hp}$ power pack skid system and the $1000 \mathrm{hp}$ power pack skid system will be assembled at TCM. The power pack skid systems include generator, supporting skid, conțrols, and other supporting auxiliary subsystems. The Stirling cycle engine system (combustion system, stirling engine, and heat transport system) will be mounted in the power pack skid systems.

The 500 hp power pack skid system will be assembled within the first 4 months of Phase V. After Engine No. 4 is assembled in Task 3, Engine No. 4 will be installed in this power pack skid and the complete $500 \mathrm{hp}$ power pack skid system will undergo durability testing during Task 4 at FMA.

The $1000 \mathrm{hp}$ power pack skid system will be assembled 19 months after the initiation of Phase $V$. Engine No. 5 and the 
rebuilt Engine No: 3 will be installed in this power pack skid and the complete $1000 \mathrm{hp}$ power pack skid system will undergo preliminary and demonstration testing during Tasks 9 and 10 at TCM.

\section{$5.9 \frac{\text { Task } 9 \text { - Preliminary Testing of } 1000 \mathrm{hp}}{\text { Power Pack Skid System }}$}

Preliminary testing of the $1000 \mathrm{hp}$ power pack skid system will be performed at TCM. The purpose of this task is to prepare this power pack skid system for demonstration testing to be performed in Task. 10.

\subsection{Task 10 - Demonstration Testing of $1000 \mathrm{hp}$ Power Pack Skid System}

Upon the completion of Task 9, the $1000 \mathrm{hp}$ power pack skid system will undergo demonstration testing at the TCM facility. A demonstration test plan will be prepared which will include the following:

- Identification of the thermodynamic properties required to define the components, subcomponents, subsystems, and overall power pack skid system performance

- Operating conditions over which the power pack skid system is to be tested

- Instrumentation required for thermodynamic property measurements

- Data reduction protocol

- End use of the electrical power developed by the system. 
The demonstration testing will provide credible information on energy consumption and efficiency, reliability, maintenance, performance, environmental effects, safety, operating costs, and other factors necessary for the commercial evaluation of the large stationary stirling cycle engine system.

\subsection{Task 11 - Commercialization Plan}

Using manufacturing assessment, cost, and thermodynamic performance data developed during Phases II through V, TCM and FMA will prepare a detailed commercialization plan for the large Stirling cycle stationary power generation system. The commercialization plan will include:

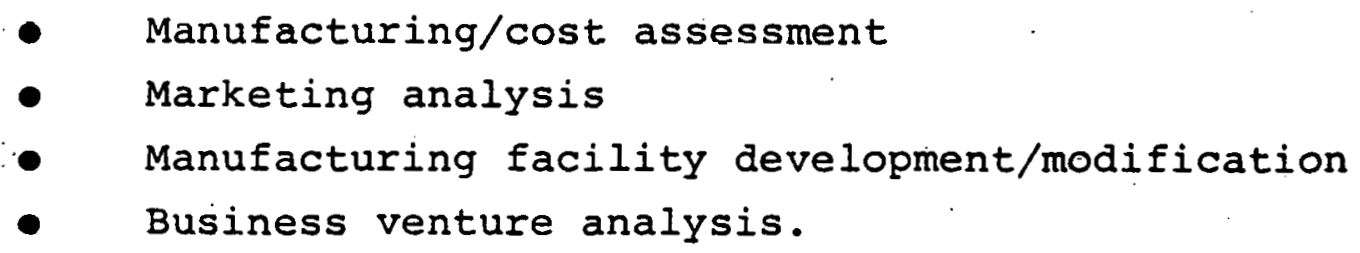

Each of these items are described in detail below.

\section{Manufacturing/Cost Assessment}

A manufacturing assessment which includes factors such as manufacturing technology, production feasibility, and power level growth potential will be performed. The technology required for the manufacture of the large stirling cycle stationary power generation system will be identified in terms of current stateof-the-art manufacturing technology, manufacturing development technology, or projected manufacturing technology. For the latter two manufacturing technology areas, the assumptions for success and the required development effort and associated costs will be discussed. A detailed table showing the major components and required manufacturing technology will be prepared with a discussion of the critical manufacturing technology assessments. 
The cost assessment will be performed. This will include the derivation of manufacturing costs both fixed and variable $\therefore$ costs for different values of quantities produced. Also part of the cost analysis will include a breakeven analysis. The breakeven analysis will indicate the profits or losses that occur for a certain quantity sold.

The initial capital investment costs, tooling costs, facilities coṣts, distribution and merchandizing costs, costs of capital, return on investment, and labor development costs will be calculated.

Finally, the potential cost savings for the consumer will be calculated for the system market segments, for example, new retrofit, commercial, etc. This analysis will be performed in two ways. A net present value savings will be calculated using an effective cost of capital based on industry average value, and an expected payback time period will be calculated. Both the initial capital cost and operating costs will be included in the analysis.

\section{Marketing Analysis}

Prior to the development of any new commercial product, it is important to perform a marketing analysis. The marketing analysis will include the following:

- A description of the market mix, that is, a description of the product, the price of the product, the promotion required for the successful introduction and continued selling of the product, and the place where the product i. will be sold 
- Identification of the market segments which include new replacement, retrofit, residential, commercial, and others

- A description of the market penetration strategy and an estimate of the product Iife cycle curve, that is, sales versus time will be prepared

- A prediction of the feasibility/applicability of the proposed large Stirling cycle stationary power generation system for the new replacement and retrofit market segments will be determined. Both technical and economical considerations will be included in the evaluation.

Other factors such as the effect of different selling prices, product size, manufacturing capital investment and material requirements, applicability to conventional manufacturing techniques, maintenance requirements, environmental effects, safety and reliability characteristic on the marketability of the proposed system will be investigated.

\section{Manufacturing Facility Development/Modification}

A pilot production plan will be developed by TCM and will include:

\footnotetext{
- Description of components and subsystems to be fabricated at the TCM engine manufacturing facility

- Manufacturing protocol required for each component

- Overall manufacturing operations including.PERT diagrams and critical path selections
} 
- Manufacturing facilities design/modification and identification of new manufacturing capital equipment.

\section{Business Venture Analysis}

Using the technical, cost and market data defined above, a business analyses will be developed. Included in this analyses are:

- : Manufacturing capital and operating costs

- Facilities requirements/costs

- Labor requirements/costs

- Market penetration/price

- Profit margin/introductory discounting

- Distribution/advertising costs

- Risk/liabilities

- Loss of volume in current products

- Cash flow analyses

- Return on investment analyses

- Consumer acceptance

- Institutional factors

- Ease of commercialization.

Consumer acceptance will be evaluated on the basis of system noise, size, reliability, maintainability requirements, toxin emissions, system location for commercial and residential applications, system adaptability to existing energy systems and ease of operation. Institutional factors include federal and state laws, technical building codes and union regulations.

Ease of commercialization includes such factors as manufacturing feasibility assessment, projected system price, market penetration evaluation and product life cycle estimate, initial venture capital investment, distribution system sales, service systcm, and identification of potential commercial manufacturers. 
The careful preparation of the commercialization plan will increase the probability of success for the product commercialization of the large stirling cycle stationary power generation system.

\subsection{Task 12 - Reports}

A detailed Phase $V$ program plan which includes a technical description of each task, a management plan, and a cost plan will be prepared within the first 2 weeks after the contract for Phase $\mathrm{V}$ is awarded.

FMA will be responsible for preparing the monthly progress reports and the finai report so that all work performed during Phase $\mathrm{V}$ is documented. The monthly progress reports will include a project status report and a cost report (Form 65).

In addition, five oral program briefings will be provided at 6-month intervals. 
Both FMA and TCM jointly prepared cost estimates for the completion of Phases II through $V$. The costs are summarized in Table 1. The costs are budgetary and were prepared on a costplus-fixed-fee basis, and do not include inflation adjustments. Thus the values are for 1980 dollars.

Table 1. Summary of Estimated Costs for Phases II Through V

\begin{tabular}{|l|r|}
\hline Phase & Estimated Cost \\
\hline Phase II & $\$ 2,374,000$ \\
Phase III & $3,437,000$ \\
Phase IV & $9,143,000$ \\
Phase V & $\frac{7,109,000}{\$ 22,063,000}$ \\
\hline
\end{tabular}

